\title{
URBAN HOUSING AND LAND USE
}

\author{
Herbert U. NelsoN*
}

An impression has spread that, in our great altruistic surge toward better housing and toward decent living places for the low-income groups, the principal opposing influence has been what is often enough referred to editorially as the selfish real estate interests. In this paper I have been asked to give the point of view of those interests.

The truth of the matter is that the surge toward a new day in housing began to rise, markedly, some time before the depression. It has back of it the whole real estate and construction industry. It is the life-force of the industry. Real estate boards have consistently opposed the method of governmental subsidy where subsidized projects would overload a neighborhood and further disorganize local values.

The point of view of real estate has been this: You cannot bring in low-cost housing or take out slums, in a way that is economically sound, unless you attack the job in the light of the city's whole need: its whole housing problem, and its whole problem of land use and land values.

\section{National Policy Should Aim At Creating Instruments}

The past months have been too much given to a discussion of projects, projects, projects. I think we will all admit this. We have yet to devise broad general means which would clear the way for a general advance. The coming months will be critical in this respect. There is every indication, as this is written, that a first chapter of federal housing history has already closed. It is seen that what was expected back in June of $193^{2}$ is not going to take place. The allotment of funds under the plan written into the National Industrial Recovery Act has not produced and evidently in our present state cannot produce equity money for projects capable of meeting the requirements of the Act.

With federal housing policies now being shaped for a new outlet it is surely well to consider what the objectives of such a policy should be. There may be indication of what is ahead in a copyrighted Associated Press story of February ig dealing with a projected major federal study of housing under four cabinet members. This study is announced as concerned not with the hundred million dollar Public Works Emer-

- Secretary and Manager, National Association of Real Estate Boards, Chicago, Illinois. Formerly organizer and secretary of the Minneapolis City Planning Commission. Mr. Nelson's proposals for a national housing program, here given, are, except where so stated, to be considered his own personal views and not in any sense a commitment of the Association. 
gency Housing Corporation fund or with new PWA allocation but with facilitating and giving direction to the expenditure of from thirty to forty billion dollars of private funds in the field of housing in the next ten years.

I submit that the most valuable assistance that the federal government can give to the whole great social movement for sound housing conditions is not through individual demonstration projects, however well conceived, nor through direct loans for individual projects, however socially desirable. It is rather through the development of helps which only government can give, through setting up instruments for very broad general use. It could, for example, organize the means of a permanent capital supply. It could open great new areas of information. It could set up methods through which we could use coöperative effort. A national housing policy can organize our existing strength for a new advance, find ways to overcome existing major difficulties, give the means and the instruments for constructive action by the people of each community. Such a national policy is not only proper to government. It is government.

Primary housing questions include: (a) cost reduction, (b) flow of financing, (c) control to balance supply and demand, and (d) legal devices to secure maximum human values. The housing problem is thus far larger than the scope chosen for this issue of Law and Contemporary Problems, and it is all one problem.

I assert that the most direct, soundest, even quickest way to bring about decent housing for low-cost groups, (or to solve the tough problem of slums and blighted areas) is through a national program to meet the whole housing problem. Only so can we go ahead with a clear sense of direction, without enormous new dislocations and waste.

The bigger job is the easier job, because it is not artificially pulling up one segment of our existing social and economic structure; it is giving the whole structure a chance to rise. It is using natural forces to make such a rise come naturally. Such a program would cost us some clear national thinking. In dollars and cents the expenditure required would be comparatively little.

As the foundation stones for a sound national housing program I propose:

I. A central mortgage discount bank, to coördinate the whole mortgage system of the country, securing a stabilization and a cost-saving which such centralization alone can give.

II. An agency (to be created either through the federal government or through coopperative action of the real estate-construction-financing industry) which would establish accurately the essential facts in each locality as to mortgage risk, And

Available to this agency, or part of it, an agency which would establish for each community the essential facts as to supply-demand.

III. New legal machinery (and business devices) through which we might draw much further than we have ever yet drawn on the principle of coopperative action to 
(a) Bring run-down areas back into condition for residential use, replat them, rule out adverse use.

(b) Extend to tenants benefits arising from coöperative endeavor.

(c) Make the home unit part of a planned neighborhood.

With these three foundation stones of a national structure I think it could be universally agreed that there should go:

IV. Modernization of the tax system to remove present handicaps against housing advance.

It may here be said that within the last year we have seen the first fairly comprehensive tax modernization programs designed definitely to this end written into our state laws.

Where the Waste Now Is. To recapitulate what has become a commonplace of discussions such as this, present excessive or prohibitive costs of good housing and home ownership are principally these:

First, (by universal assent) over-high financing costs.

Second, over-high land-utilization costs. (Arising from poor grouping; excessive street area; failure to differentiate between investment and speculation; ctc.).

Third, disorganized condition of the home building industry. (Failure to utilize pre-fabrication, mass production, economical new materials or methods, vertical organization of the industry, etc.)

Fourth, demoralization of the tax system, both as to state and local direct tax and as to special assessments.

Fifth, poor planning in the large sense, a sense larger than is in the control of any single individual. Evidenced in: poor correlation between supply and demand, over-and under-building; failure of zoning laws or building ordinances to reach their objectives; over-subdividing, with its huge cost to the community for unused streets, sewers, and the like; hodge-podge growth, resulting in blighted districts unable to support their governmental costs, a burden on the tax payer at large, and so on all home and property ownership.

My four-stone proposal for a federal housing program covers every one of the great factors now operating to produce over-high housing costs, save only one, our technological medievalism in housing, our failure to use what we already know in our building methods and business methods. Correction of that factor, surely, can quite safely be left to private initiative. It will come into line almost on the instant, once the other factors are met. ${ }^{1}$

\section{Separate Systems for Long-Term Credit}

The proposal for a federal system of long-term credit banks to unify the mortgage structure, made as early as May I93I by the National Association of Real Estate Boards, is exactly parallel with the proposal for twelve new discount banks ("intermediate credit banks") for loans to small industries placed before President Roosevelt

\footnotetext{
${ }^{1}$ Experimentation, in new materials, new processes, mass methods, is going on now, bchind closed
} doors, in almost every major manufacturing industry concerned with home building. 
(February 2r, 1934) by Eugene R. Black, governor of the Federal Reserve Board. ${ }^{2}$ The Black Plan is avowedly to bring needed federal help, financial and legislative, to set private credit in motion. It is premised on the theory that any real recovery must be financed by private credit, not by "easy money." Such a premise applies strongly to low-cost housing.

The whole profound disorganization of our mortgage structure during the depression came essentially because of this fact: It was founded on the ability of the individual to pay on demand. That is a false foundation. We have failed to found it on its true basis, the ability of the underlying property to sustain sound use-value over a long period of time.

Our financing system is a historical, not a logical growth. We have habitually intermingled, in our banking practice, funds that for any safety should have been kept liquid and funds that properly and for most profit should have been placed in long-term investment. Because the two were tied together, when the crash came we could not call out our short-term funds, we could not borrow against our longterm funds. We lost faith in our bankers; our bankers lost faith in us. Credit collapsed. Values collapsed.

We face, still, a situation in which there is no present financing available for any type of new construction.

Commercial banks, in this crisis, were sustained in great measure through the Federal Reserve system; building and loan associations through the Home Loan Bank system; both, in addition, (with insurance companies) through the R. F. C. But none of these agencies is open for discounting on the individual mortgage, however sound. The earth tremor shook each mortgage obligation as a unit, and many fell.

The Federal Mortgage Discount Bank would introduce what engineers would call a cantilever principle into mortgage financing. It would operate much as the cantilever principle operates in Wright's revolutionary design of the Imperial Hotel in Tokyo. In time of tremor, the structure would move on its own base, but would not collapse. ${ }^{3}$

Surely any national plan for the creation of shelter calls, once and for all, for a separation of long-term and short-term credit in our banking structure. I believe that this simple act of separation would set up such security as would draw capital into new housing enterprises to whatever extent social need or new advance in living standards might incite such projects.

\footnotetext{
${ }^{2}$ It is in line, also, with the earlier proposal of Frank A. Vanderlip for a general long-term credit system for all industry.

a The remarkable work of the Home Loan Banks, two of which are already on a dividend basis, would give a start infinitely more valuable than any theory. The plan proposed is in line with the whole Federal policy for reorganization of commercial banks.

In time of panic, savings should flow into a Federal mortgage discount system, not out of it, because the system would have back of its bonds a major portion of the urban land resources of the country, unquestionably our most permanent and stable single capital resource.
} 
We cannot segregate one group of mortgages, one group of financing institutions, one group of housing projects, and hold that little group safely against economic collapse. The depression has taught us that. Low-cost housing, unless it is to draw one hundred per cent on federal funds universally from this time forth, will find its clearest path to financing the broad general path, through a general federal mortgage discount corporation or other federal mortgage bank.

\section{Proposal to Rate Communities On Their Mortgage Risk}

We have talked a long time about the over-high cost of mortgage interest. We have done little to establish, factually, what mortgage risk is, what interest rates should be. I should like to see set up, as a second foundation stone for a national housing structure, a national risk-rating agency for housing loans, as proposed recently by Mr. J. Soule Warterfield, Chicago, president of the new National Association for Better Housing.

He suggests that there be created a national bureau or laboratory similar to that which for years fire insurance underwriters have had in operation to gauge the risk of insurance and so establish its cost. The underwriters' laboratories give each city a schedule of insurance rates based on the risks run in that city. Each community is credited for the number of its fire-stops, debited for the number of its shingle roofs, and so on. The city with a good fire department, for example, gets a lower general rate than the one with a poor department, in proportion to the lower risk involved. Inside their base rate for the community, rates are established for various types of buildings. The building which is a low hazard gets a low rate.

It should be possible to set up a similar laboratory through which to measure the factors which condition the risk of a mortgage loan, and through which we might establish for each community base schedules for mortgage interest rates in proportion to the risks which home ownership or mortgage lending encounters in that community.

Such a laboratory might raise such questions as the following: Has the town a good zoning ordinance, one that is an actual and adequate protection to real estate values? Does the town have a good building code? Does it have an honest administration of the building code? Does it have a building department that makes adequate inspections? Is the special assessment system equitable? Are foreclosure and redemption laws disadvantageous to mortgagee? Are the laws such that primary liens are liable to be thrown ahead of a mortgage unexpectedly?

Shifting neighborhood uses have, in our past history, been the biggest single element of the lender's risk. The proposed laboratory would ask whether the town has huge blighted areas or areas that threaten to become blighted. ${ }^{4}$

Clearly the proposed laboratory would need, as its very first equipment, data to

- A good school system would count as a decided factor for stable real estate values in a community. Good health protection would have some wcight. The question of adequate recreation facilities would enter in, but would be more remote. 
indicate the existing supply in each city of each type of structure, the amount of vacancy in existing structures, and the recent trend of new demand. It would need access to the findings of such a real property inventory as is now being made. Surely having once undertaken such an inventory, we shall never again fail to make the same kind of examination periodically. If a detailed study of demand and supply is not continued through the Bureau of Foreign and Domestic Commerce, then it must be undertaken, to some degree, jointly or severally, by every agency which seeks to measure mortgage risk.

It would be advantageous, and would probably be found necessary, to have the risk factors measured for each neighborhood of the city as well as for the city as a whole. Inside the base rate there would be rates for individual structures. ${ }^{5}$

The fire underwriters' laboratory has brought a tremendous pressure on each community for acceptable fire protection measures. Local authorities act, because what they do means millions of dollars to the citizens of the community in lowered costs for fire insurance.

Establishment of a rating agency for mortgages would, in the same way, bring a gigantic economic pressure on municipal officials to give their people lower risks for mortgage financing and home ownership. When good zoning enforcement, good building inspection, protection against shifting land use, mean dollars and cents to the people of the city in their interest rates or in the selling price (discount rate) of their mortgages, we shall have, for the first time in this respect, a concentration of force upon city administrations for constructive action.

The question arises: What agency should carry on such an undertaking?

The job proposed is a vast job. There always is a danger of political pressure creeping in to affect the findings of a governmental agency. On the other hand, the federal government may be the only agency through which such an undertaking, in its broadest scope, is at present feasible. The Housing Division is a possible locus. The federal real property inventory, analyzed by the Bureau of Foreign and Domestic Commerce, has in it the germ of the whole attempt. Certainly a federal mortgage discount bank might make tremendous use of risk studies, and might itself set up a risk-measuring system. It might go as far as to say, "We will discount paper from town $A$ at a base rate of 80 per cent, paper from town B at 60 per cent," etc.

The new National Association for Better Housing, the first agency we have ever had for coördinate action of architects, engineers, materials manufacturers, contractors, builders, realtors, financing agencies and social agencies in the field, has before it a proposal that it go to work, at once, on the outline of a mortgage risk-rating

\footnotetext{
${ }^{B}$ For individual structures (or neighborhoods) these things would count: adequate transportation, adequate public improvements and service, proper neighborhood planning, protection through deed restrictions, protection through community control of architectural design. Sound construction, sound architecture would come in. But inquiry as to mortgage risk must address itself primarily to fundamental social factors.

The proposal I am making has, thus, little in common with any plan for "certification" of houses themselves, primarily on their physical characteristics, as a grade A, grade B or grade C mortgage risk.
} 
bureau. A rating bureau might be supported by joint action of the various lending agencies. These might act through their national trade groups, or through their respective code authorities. ${ }^{6}$

\section{New Legislative Machinery to Reverse Process of Decay}

\section{(a) Coöperative Neighborhood Reconstruction}

I propose as the third stone in a national housing structure such enlargement or modification of our laws as would authorize group action of the property owners within a given neighborhood to re-zone, re-plat, rebuild or otherwise reconstruct the neighborhood so as to enhance its quality as a home neighborhood.

We have, now, no legal instrument through which owners in a "blighted" or "slum" area can come together, in a practically effective way, to change the character of the neighborhood. Zoning laws, at the best, protect only against new invasions of adverse use. They give no lever through which the people of a district may, by majority coöperative action, throw out an adverse use. Theoretically, eminent domain may be invoked. Practically the whole PWA search of past months for suitable rehousing projects on which to loan showed how fatally over-expensive is the ancient method of condemnation as a means of assembling land in a given district for re-platting or re-planning.

I believe, enthusiastically, with Louis Brownlow, Director of the Public Administration Clearing House, that the real unit of home planning can no longer be the individual home. It must be the neighborhood. I believe, second, that the individual single family dwelling, rather than the multi-family structure, is the prototype of good housing and of good social planning. I believe, further, that coöperative endeavor is as sound in housing as it is in mutual insurance or banking. Tying together these three convictions, I have offered in some detail one proposal for reversing the process of urban decay.

The crux of this plan, which has had some discussion under the title Home District Plan, is its proposal to extend the police power to properly constituted new neighborhood units set up in such a way that they may, under equitable conditions, wipe out adverse use.

The proposal is, essentially, to convert present diverse ownerships within an area into a new form of corporate ownership. Action might be on vote of possibly 75 per cent of the property owners owning 75 per cent of the area affected. This new coöperative ownership unit, under supervision of a state or local housing authority, could properly be given quasi-public powers. It would, in fact, partake of the

\footnotetext{
- Agencies who could act thus include investment banks, mutual savings banks, building and loan 2ssociations, real estate mortgage companies, and possibly mutual insurance companics. As a matter of fact, the life insurance companies are already attempting something of the kind, each on their own account. For example, a leading national authority on real estate appraisal is now making a survey of various cities for the Prudential Company, essentially so they may know where it is safe to lend on martgages.
} 
nature of a subordinate unit of government. It would be set up in somewhat the same way as a public utility corporation.

As part of a program of slum clearance, the federal government or the municipal housing authority borrowing from the federal government might very properly be authorized to purchase directly the first lien bonds of such a Home District.

Whatever may prove the successful lever for raising blighted areas, we can no longer afford to think of our existing housing, including our owned homes, as astronomers for a long time thought of the cosmos-as a system continuously and inevitably running down. We must search for a way to set our slums, our still-born subdivisions, our ordinary hodge-podge neighborhoods, on the up path. One very valuable Public Works housing project might very well be the development of a model state law helpfully outlining a legal device for empowering proper units to rule out adverse uses and effectively replan present blighted areas.

(b) Extension of Coöperative Principle Through New Forms of Tenant-Participation

We have still to find a workable method to do what limited dividend corporations originally were proposed to do: provide decent housing (not necessarily new housing) for the low-income group. I believe that we might devise forms of action which would bring to tenants in this group the benefits of the coopperative principle.

We cannot expect sound housing projects through spontaneous coöperative action by this and that knot of people for their own housing. Sporadic groups of people who might naively band together for such action do not know how to achieve a sound project. They do not know real estate, do not know construction, do not know the quirks of the legal structure involved, do not know real estate financing. But I believe we might utilize the coöperative principle through people who do know how to create a successful project, in ways such as this:

There might be set up by a group of citizens (acting without salary, as is now done in organizing a building and. loan association) a Coöperative Housing Society, which, drawing on practical and experienced organization and management, might (I) buy or build apartment buildings for rental; (2) develop single-family home areas. The plan would be such as to retire the capital in approximately 20 or 30 years, providing, every year, a small "undistributed dividend."

In the case of apartment buildings every tenant, at the end of each year of occupancy, would be credited with his share of this "dividend" for that year. He could not draw out his dividend, but in case he incurred sickness or unemployment and could not pay his rent the amount would be available and be applied to cover his current rent bill. If he moved from the apartment the accumulated "dividend" would have a certain cash surrender value, such as is given life insurance policies. Persons remaining in a building conducted on this coöperative principle might accumulate sufficient coöperative interest in the building's earnings to assure them, 
after a time, rent-free quarters over a considerable period in the building or in another of equal quality under the same Coöperative Society.

If the Society developed a group of small houses it might rent them under a somewhat similar plan. Such a rental plan would have some of the features of a 20-year endowment insurance policy, and should lead to complete ownership.

A plan of this general type would open up true coöperative housing of a practical kind. The difficulty of ascertaining what the risk would be is not so great as that overcome by insurance companies in establishing their risk tables.

\section{(c) Development of Home Ownership to Include} Neighborhood Control

I believe in coöperative housing. I believe that under urban conditions, conditions too big for any small home owner to buck alone, we need a new type of home ownership-some form which would include in effect coöperative ownership of the whole neighborhood.

The purchaser in a high-grade subdivision gets something like this when he buys his lot, through the restrictions imposed upon his neighbors in perpetuity, and through the community control set up over neighborhood areas dedicated to parks and playgrounds. But the isolated home owner, who goes out on a forty foot lot and builds a house, has no way of buying a sphere of influence around his little holding. Further, he has no way of spreading the risk which he undertakes, including the risk of encountering a bad builder, the risk of refinancing-or, for that matter, of financing-the risk of unexpected special assessments. If, on the other hand, he were part of a large coöperative agency, such, for example, as the Home District above proposed, he would be buying what he wants to buy,-a dwelling, plus a livable neighborhood-and he would be sharing his risk with many people.

I believe that for the average-income group in the future, coöperative housing, probably in various forms, is the way to satisfactory living. It will take leadership and skill to develop methods. The end is worth the effort.

\section{Modernization of the Tax System}

As the basis for a modernization of the tax laws to give a better situation for home ownership and good housing generally, I propose this 6-point program, which has been suggested for state action by the National Association of Real Estate Boards:

I. State control of local tax levies and bond issues, under proper safeguards.

2. Limitation of the property tax by state constitutional provision.

3. Spread of school costs to a wider tax base.

4. Expenditure of funds from state gas and vehicle taxes upon city streets as well as upon rural highways.

5. Restriction of use of special assessments for financing public improvements.

6. Consideration of the income or use value of property as one of the major factors in arriving at a fair assessment for tax purposes. 
Widening of the tax base and transfer of school costs in greater measure to the state are perhaps the leading present tendencies in the great wave of state tax legislation of the past year and a half. The movement for all-over tax limitations, frankly a forcing measure to bring widening of tax base, has already gained tremendous momentum.

\section{Current Rush for New State Legislation}

It is perhaps natural that in attempting, as we must, to ride two horses at the present time, reëmployment and low-cost housing advance, we have, in our governmental policies, yielded rather over-much, for a time, to the demands of the emergency. It is not strange that in formulating any national policy on the question of low-cost production, for years in a state of flux, we have first had to develop some understanding of the real problems. This has been true of all of us, federal officials, local officials, groups of citizens interested in social advance, the economists, the legal minds who must be called on to implement any program, the technological investigators, and individuals and organized industries all down the line engaged in the production of homes and housing.

First aftermath of the federal housing policy as sketched in the National Industrial Recovery Act was a series of legislative rushes to set up state housing laws under which "easy money" could reach the local communities, and a concomitant rush of projects attempting to get under the Act. It is now found that the emergencymade state housing commissions have not brought their cities the hoped-for federal money. We are, therefore, in for a new set of legislative rushes. This time they are for municipal or other housing authorities which can be given 30 per cent federal grants. Unfortunately for any thoughtful evolution of long-term housing policies, the available $3^{0}$ per cent grants to public housing projects, advertised in every discussion, became inevitably the focus of public attention. For the purposes of the emergency there must, of course, be discussion of how states may get into the race for that $3^{\circ}$ per cent federal money. But I think we may agree that we expect, and have a right to expect, that our leaders give thought-and their major thought-to consideration of how any housing authority, or housing administration, may safeguard against costly incidental dislocations, and go after permanent needs. If we let that available $3^{\circ}$ per cent warp either our projects or our long-term policies, the cost is likely to be high.

Housing may look like a problem in "urban pathology." It is rather a problem in constructive urban physiology. We must, eventually, get away from a federal housing dole and set housing activity on its own feet, justifying itself to its own banker backing on the basis of its own economic soundness. Blood transfusion from. the federal veins may be necessary to start normal processes going again. I believe that the aim of our national housing policy must be to set up a system through which blood transfusion will not be needed every day. 